\title{
Nowa głowica do orbitalnego doczołowego spawania rur metodą TIG
}

\section{New TIG welding head for orbital butt joining of pipes}

\section{Streszczenie}

Do jakościowego, doczołowego spawania metodą TIG obwodowych złączy cienkościennych rur, prefabrykatów, a nawet fragmentów całych instalacji stosowane są wysoce wyspecjalizowane urządzenia do spawania orbitalnego metodą TIG. Pomimo wysokiej ceny urządzeń pochodzących wyłącznie z importu oraz pewnych ograniczeń funkcjonalnych, wysoka wydajność, jakość i powtarzalność połączeń skłaniają do ich zakupu. W artykule przedstawiono proces opracowania i efekty wdrożenia do produkcji przemysłowej nowego, krajowego systemu do orbitalnego doczołowego spawania rur metodą TIG, zrealizowanego w ramach projektu celowego FSNT-NOT w latach 2012-2013.

Słowa kluczowe: automatyzacja, spawanie TIG, spawanie orbitalne

\section{Abstract}

High quality TIG girth welding of thin-walled pipe joints or other parts of metallic structures are usually made with the use of highly specialized equipment produced by a few manufacturers. Investment in such equipment resulted from an ability to perform high quality joints and high efficiency despite relatively high price and sometime some limitation of application. The course of design, assembly and implementation to industrial practice of a new automatic system for orbital TIG welding of butt pipe joints supported by the FSNT-NOT grant within the years 2012-2013 is described in this paper.

Keywords: automation of welding, TIG welding, orbital welding

wymagania jakościowe są wystarczającymi przesłankami do zastąpienia pracy spawacza procesem zautomatyzowanym. W tym celu stosowane są odrębne, wysoce wyspecjalizowane urządzenia do doczołowego spawania orbitalnego rur metodą TIG. W takim przypadku to głowica spawalnicza (elektroda TIG) musi wykonać ruch na całym obwodzie nieruchomego złącza, a parametry technologiczne powinny być dostosowane do bieżących warunków procesu.

Podczas pracy ręcznej, wykonywanej nawet przez doświadczonego spawacza, mogą powstać niekontrolowane braki przetopu, a w przypadku spawania swobodnego (bez specjalnego oprzyrządowania montażowego), także przesunięcia krawędzi łączonych elementów i inne błędy geometrii (rys. 1a). Przy zautomatyzowanym spa-

Dr hab. inż. Andrzej Kolasa, prof. PW; dr inż. Paweł Cegielski - Politechnika Warszawska, Andrzej Oneksiak - ZASO Zakład Aparatury Spawalniczej. 
waniu orbitalnym TIG głowica spawalnicza wykonuje obwodowy ruch roboczy wokół nieruchomego złącza. Właściwie zastosowana maszyna zapewnia najwyższą jakość połączenia (rys. 1b), jednak warunkiem uzyskania pełnej powtarzalności efektów jest zapewnienie równie powtarzalnych właściwości łączonych elementów. Końce rur muszą być starannie przygotowywane do spawania i wolne od zanieczyszczeń. Dla rur o najcieńszych ściankach zgrubne cięcie mechaniczne może nie być wystarczające. W przypadku grubszych ścianek konieczne jest odpowiednie ukosowanie ich krawędzi.
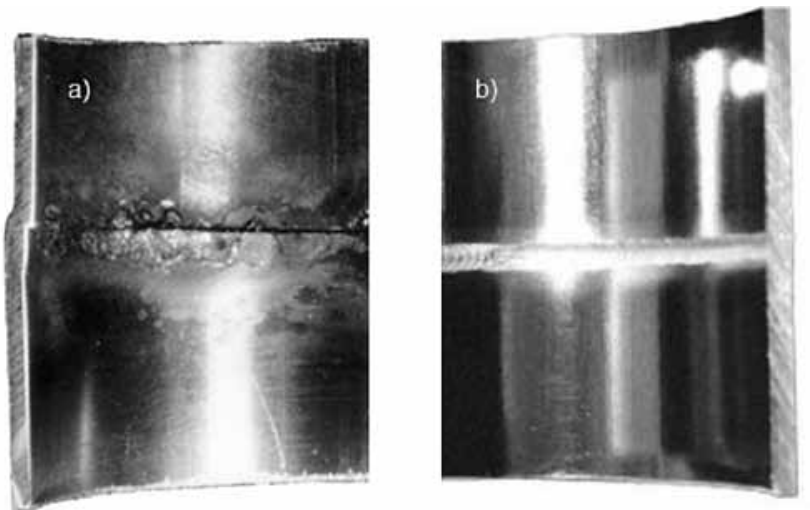

Rys. 1. Złącza obwodowe wykonywane metodą TIG (fragmenty rur, widoki od strony grani): a) ręcznie, b) głowicą orbitalną TIG [1, 2]

Fig. 1. TIG welded pipe joints made manually (a) and with the use of automatic head (b) $[1,2]$

Istotną trudnością przy spawaniu orbitalnym TIG, w którym ruch obwodowy głowicy roboczej następuje wobec nieruchomego złącza, jest zapewnienie wysokiej jakości połączenia pomimo zmieniających się warunków spawania podczas procesu. Powodem trudności technologicznych są następujące, główne czynniki:

- nagrzewanie się złącza w miarę postępującego procesu, istotne zwłaszcza przy spawaniu rur cienkościennych i o małych średnicach,

- zmieniająca się pozycja spawania w poszczególnych fazach procesu dla złącza rurowego, którego oś jest odchylona od pionu.

Dla spawanych rur o osiach zorientowanych pionowo proces odbywa się przy stałej pozycji naściennej (PC, rys. 2a). Dla poziomej orientacji osi rur proces przebiega w aż czterech różnych pozycjach: podolnej a)

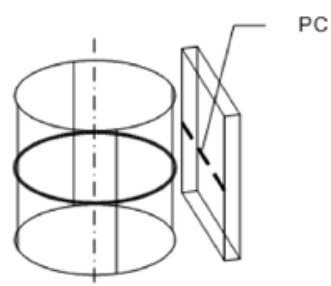

b)

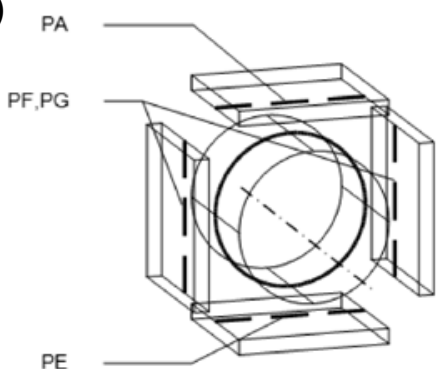

Rys. 2. Pozycje spawania złącza obwodowego przybliżone do pozycji spawania jednakowo zorientowanych w przestrzeni spoin liniowych: a) dla pionowej, b) dla poziomej osi łączonych rur [1, 2] Fig. 2. Welding positions of pipe joints with vertical axe (a) and horizontal axe (b) [1, 2]
PA, pionowej z dołu do góry PF, pionowej z góry na dół PG i pułapowej PE (rys. 2b). Zgodnie z PN-EN ISO 6977 spawanie takie określa się jako spawanie w pozycji PF lub PG.

Wymienione trudności pokonywane są przede wszystkim przez:

- zastosowanie głowic roboczych o bardzo wysokiej precyzji, zapewniającej powtarzalne parametry ruchu (prędkości, trajektorii, brak luzów mechanizmu napędzającego itp.),

- programowanie parametrów spawania w wydzielonych strefach na obwodzie złącza.

W ramach podstawowego podziału wyróżnia się następujące odmiany głowic orbitalnych TIG [1, 2, 4]:

- zamknięte (także kasetowe), przeznaczone do rur o najmniejszych średnicach,

- otwarte, stosowane w najszerszym zakresie średnic i konstrukcji spawanych,

- w postaci wózków szynowych, poruszających się po specjalnej bieżni dookoła rury, przeznaczone do spawania elementów o największych średnicach (także metodami MIG/MAG).

Głowice zamknięte są przeznaczone do spawania cienkościennych rur i kształtek, przede wszystkim ze stali wysokostopowych. Dostępne są w różnych wielkościach, umożliwiających spawanie rur o średnicach zewnętrznych nawet poniżej $2 \mathrm{~mm}$, do ok. $80 \mathrm{~mm}$. Ruchomy pierścień z elektrodą wolframową znajduje się w komorze gazowej utworzonej przez zewnętrzną obudowę głowicy (rys. 3), stanowiącą jednocześnie układ zaciskowy dla spawanych rur (obudowa pełni funkcję szczęk mocująco-centrujących). Taka konstrukcja zapewnia jednocześnie maksymalną ochronę złącza gazem osłonowym. Wymieniając elementy zaciskowe obudowy, można w pewnym zakresie dostosować głowicę do średnicy rury. Sam proces spawania odbywa się bez dodawania spoiwa z zewnątrz oraz bez możliwości poprzecznej oscylacji elektrody.

Głowice otwarte są najbardziej uniwersalnym środkiem do spawania obwodowego metodą TIG cienkościennych rur, kształtek i kołnierzy, przede wszystkim

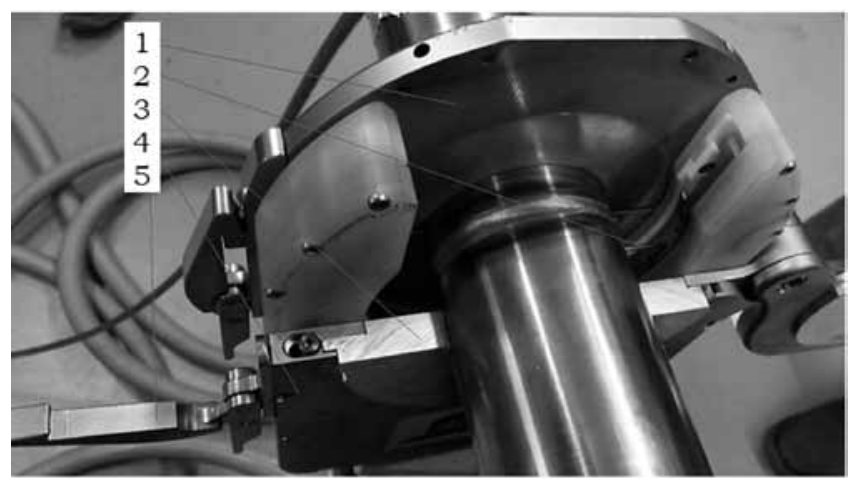

Rys. 3. Głowica zamknięta - widok po częściowym otwarciu: 1 - ruchoma szczęka, 2 - elektroda wolframowa, 3 - wymienna wkładka zaciskowa, 4 - podstawa głowicy, 5 - zatrzask mocujący szczęki dociskowej (A21PRH, seria 6-76, ESAB)

Fig. 3. Partly opened welding head: 1 - moving clamp, 2 - tungsten electrode, 3 - exchangeable clamp insert, 4 - head body, 5 - clamps lock (A21PRH, 6-76 series, ESAB) 
ze stali wysokostopowych. Dostępne są w różnych wielkościach, umożliwiających spawanie rur o średnicach od ok. 8 do $200 \mathrm{~mm}$. Ruchomy pierścień z elektrodą wolframową nie jest osłonięty, a mocowanie i centrowanie głowicy najczęściej jest zrealizowane za pośrednictwem ręcznie zaciskanych szczęk (rys. 4). Taka konstrukcja zapewnia jedynie standardową ochronę złącza gazem osłonowym. Jednocześnie jednak proces może odbywać się z dodatkiem spoiwa, zimnego lub gorącego, podawanego z wbudowanego lub zewnętrznego układu podawania i zasobnika drutu. Możliwa jest także poprzeczna oscylacja elektrody oraz automatyczna korekta jej odstępu od materiału spawanego.

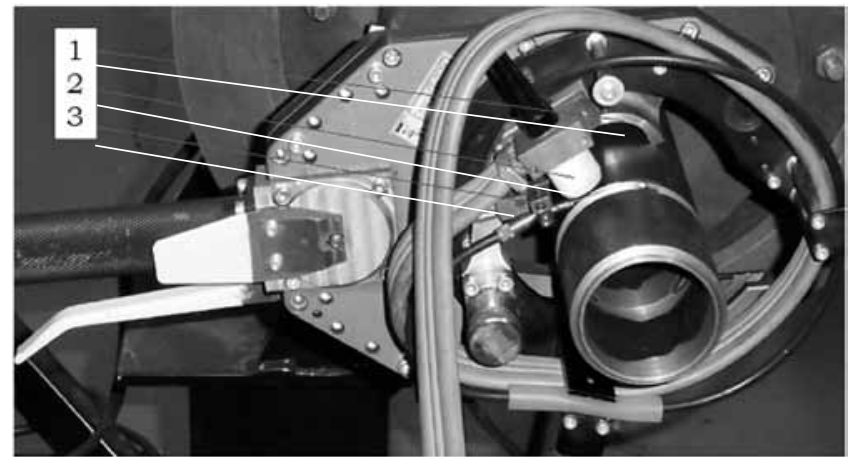

Rys. 4. Głowica spawalnicza otwarta podczas prób: 1 - szczęka mocujaco-centrujaca, 2 - uchwyt elektrodowy TIG, 3 - układ podawania spoiwa (A21PRC, seria 33-90, ESAB)

Fig. 4. Opened welding head under tests conditions: 1 - fixing and centering clamp, 2 - TIG electrode holder, 3 - filler wire feeding nozzle (A21PRC, 33-90 series, ESAB)
Głowice orbitalne przeznaczone sa do współpracy z zewnętrznymi, specjalizowanymi źródłami energii i układami sterowania, z którymi są łączone za pośrednictwem wiązek wielofunkcyjnych przewodów. Nowoczesne układy sterowania umożliwiają precyzyjne zaprogramowanie całego cyklu roboczego, w tym zsynchronizowanie poszczególnych faz ruchu obwodowego elektrody z funkcjami i zmiennymi parametrami procesu (podział na sektory, tabl. I). Dostępne są następujące, główne funkcje i właściwości układów sterowania (wybór zależnie od typu urządzenia i opcji wyposażeniowych) [1, 2]:

- automatyczna korekta żądanej odległości końca elektrody od materiału (najczęściej przez pomiar napięcia łuku),

- zaprogramowany, wcześniejszy nadmuch gazu osłonowego, a następnie jego pozostawienie przez określony czas po zakończeniu spawania,

- synchronizacja zmian prądu spawania (także z pulsacją) i podawania dodatkowego spoiwa $z$ fazami ruchu obwodowego elektrody TIG wokół złącza,

- programowane nałożenie końca spoiny na jej początek (tzw. przekrycie), zapobiegające nieszczelności połączenia,

- możliwość przechowywania w pamięci wewnętrznej, drukowania lub przenoszenia programów, np. przez port USB,

- układy sterowania zintegrowane z systemami monitorowania parametrów lub kompatybilne z tego typu systemami zewnętrznymi,

Tablica I. Przykładowe parametry uwzględniające podział złącza na siedem sektorów, dla warstwy wypełniającej (głowica otwarta A21PRC, seria 33-90, ESAB)

Table I. An example of welding parameters divided into seven parts of a girth welded joint (A21PRC, 33-90 series, ESAB)

\begin{tabular}{|c|c|c|c|c|c|c|c||}
\hline $\begin{array}{c}ø \text { 60 } \\
\text { Wypełnienie }\end{array}$ & Sektor 1 & Sektor 2 & Sektor 3 & Sektor 4 & Sektor 5 & Sektor 6 & Sektor 7 \\
\hline Punk przerwania, & 0 & 72 & 144 & 216 & 288 & 360 & 367 \\
\hline Wartość szczytowa, A & 150 & 148 & 146 & 144 & 142 & 140 & 0 \\
\hline Baza, A & 110 & 110 & 110 & 110 & 110 & 110 & 0 \\
\hline Puls, A & 0,4 & 0,4 & 0,4 & 0,4 & 0,4 & 0,4 & 0,4 \\
\hline Baza, s & 0,4 & 0,4 & 0,4 & 0,4 & 0,4 & 0,4 & 0,4 \\
\hline Nachylenie, s & 1 & 8 & 8 & 8 & 8 & 1,9 & 10 \\
\hline Wartość szczytowa, cm/min & 110 & 110 & 110 & 110 & 110 & 0 & 0 \\
\hline Baza, cm/min & 110 & 110 & 110 & 110 & 110 & 0 & 0 \\
\hline Nachylenie, s & 0 & 0 & 0 & 0 & 0 & 0 & 0 \\
\hline Prędkość, mm/min & 115 & 115 & 115 & 115 & 115 & 115 & 115 \\
\hline Kierunek & dalej & dalej & dalej & dalej & dalej & dalej & dalej \\
\hline Z pulsem & wył. & wył. & wył. & wył. & wył. & wył. & wył. \\
\hline Nachylenie, s & 0 & 0 & 0 & 0 & 0 & 0 & 0 \\
\hline Spoina, s & 5 & 0 & 0 & 0 & 0 & 0 & 10 \\
\hline Start, s & 0 & 0 & 0 & 0 & 0 & 0 & 0 \\
\hline Rdzeń, s & 0 & 0 & 0 & 0 & 0 & 0 & 0 \\
\hline Obrotu
\end{tabular}


- możliwość szczegółowej analizy zapisanych danych z monitorowania, w tym parametrów spawania, zakłóceń w ich przebiegu czy efektywnego czasu pracy urządzenia itp.,

- możliwość programowania off-line (na zewnętrznym komputerze), a następnie wprowadzenia programu do rzeczywistego urządzenia.

\section{Założenia projektowanego systemu orbitalnego}

Wobec braku krajowego systemu orbitalnego TIG oraz sygnalizowanego zapotrzebowania na rozwiązania alternatywne, podjęto działania mające na celu wdrożenie w firmie ZASO nowej generacji urządzeń, konkurencyjnych pod względem ceny i poziomu technicznego do dostępnych na rynku urządzeń [5]. Innowacyjność projektu polegała na przełamaniu ograniczeń międzysystemowych dotychczas oferowanych urządzeń orbitalnych - połączeniu w jednym urządzeniu najwyższej precyzji i ochrony złącza jak w głowicach zamkniętych, z podwyższonym zakresem średnic spawania i podawaniem dodatkowego spoiwa, typowych dla głowic otwartych. Do głównych parametrów użytkowych projektowanego systemu zaliczyć należy [3]:

- kompletny, uniwersalny system do zautomatyzowanego, orbitalnego doczołowego spawania rur metodą TIG w zakresie średnic od 20 do 120 mm (rys. 5),

- spawanie TIG bez i z dodatkiem spoiwa, podawanego w postaci tzw. zimnego drutu $(0,6 \div 0,8 \mathrm{~mm})$,

- głowicę zamkniętą, z ruchem obwodowym elektrody względem nieruchomego złącza,

- maksymalną ochronę złącza - obudowa głowicy jako komora gazu osłonowego,

- możliwość zainstalowania opcjonalnego, dodatkowego ruchu oscylacyjnego elektrody,

- nadrzędny układ sterowania z programowaniem automatycznych cykli spawania, w tym zmiennych parametrów w funkcji pozycji elektrody na obwodzie złącza (sektorów),

- mechaniczną korektę odległości elektrody od powierzchni spawania.

Zakład Inżynierii Spajania Politechniki Warszawskiej we współpracy z grupą produkcyjną ZASO z Warszawy od wielu lat stymuluje prace badawczo-rozwojowe

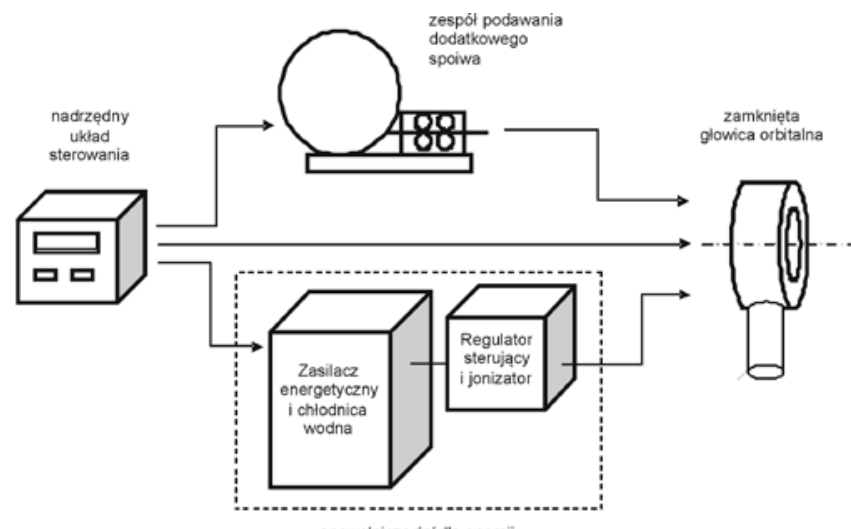

Rys. 5. Zrealizowana konfiguracja systemu do orbitalnego doczołowego spawania rur metodą TIG

Fig. 5. TIG welding system for orbital joining of pipes i wdrożeniowe w obszarze automatyzacji procesów spawalniczych. Poniżej przedstawiono efekty ostatniego opracowania, zrealizowanego w ramach jednego z projektów celowych [5].

\section{Modelowanie systemu orbitalnego}

Z uwagi na wysoki stopień złożoności projektowanego systemu, w tym brak komercyjnych rozwiązań o podobnej funkcjonalności i parametrach użytkowych przyjęto, że jego projekt i wykonanie poprzedzone zostanie opracowaniem, wykonaniem i badaniami modeli doświadczalnych: wirtualnych i fizycznych.

$Z$ uwagi na charakter modeli doświadczalnych, w tym konieczność sprawdzenia licznych wariantów mechanicznych i sterowania, nie osiągały one parametrów założonych dla prototypów i wdrożenia. Odnosiło się to przede wszystkim do wytrzymałości mechanicznej, powtarzalności parametrów oraz funkcjonalności. Powyższe odstępstwa podyktowane były względami ekonomicznymi i praktycznymi (łatwość budowy, badań itp.) i nie miały wpływu na przebieg dalszych badań. Obok modelu zamkniętej głowicy orbitalnej powstały także modele uproszczonego układu sterowania automatycznego i układu podawania dodatkowego spoiwa, niezbędne w procesie uruchomienia i badań głowicy.

W odniesieniu do modelu doświadczalnego zamkniętej głowicy orbitalnej uznano, że największą trudnością będzie zapewnienie precyzyjnego ruchu obwodowego głowicy wokół złącza, niezakłócone zasilanie nietopliwej elektrody energią elektryczną, a także podawanie gazu osłonowego oraz dodatkowego spoiwa do komory spawania. Z rozeznania realizatorów projektu wynikało, że obecnie nie jest produkowana jakakolwiek głowica zamknięta z zewnętrznym podawaniem dodatkowego spoiwa w postaci drutu. Nie było więc odpowiedniej wiedzy na temat tego typu konstrukcji oraz doświadczeń z ich eksploatacji. Opracowanie modeli fizycznych poprzedzono modelowaniem komputerowym, włącznie z wizualizacją przestrzenną 3D, w tym sprawdzeniem działania animowanych modeli na ekranie komputera (rys. 6). Pozwoliło to na optymalizację konstrukcji, m.in. pod kątem działania mecha-

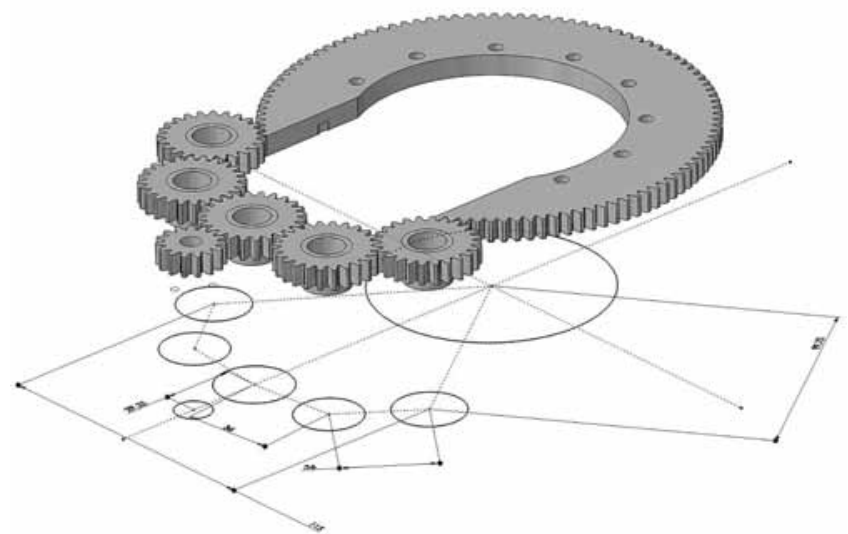

Rys. 6. Model konstrukcyjny mechanizmu napędowego - przykładowa wizualizacja 3D z możliwością sprawdzenia działania na ekranie komputera

Fig. 6. Model of welding head driving mechanism - 3D visualization 
nizmów przeniesienia napędu (rozmiaru kół zębatych, przełożenia itp.), łożyskowania wewnętrznej tarczy obrotowej, mechanizmu mocowania głowicy na spawanych elementach czy ogólnych wymiarów głowicy.

W rozwiązaniu konstrukcyjnym głowicy zastosowano innowacyjny system wewnętrznego łożyskowania, pełniącego jednocześnie rolę układu przekazywania prądu zasilającego obwód spawania. Wyeliminowało to konieczność stosowania wewnętrznych kabli i złączy. Napęd oparto na serwonapędzie elektrycznym z przekładnią zębatą.

Montaż głowicy na spawanych elementach następuje przez zamknięcie jej dwuczęściowego korpusu za pośrednictwem wymiennych wkładek dopasowujących (rys. 7a). Podczas badań, w tym prób ruchowych i spawalniczych (rys. 7b), modyfikowano i usprawniano mechanizmy: przenoszenia ruchu, kontroli położenia głowicy, mocowania i centrowania spawanych rur itp. Opracowany i zbudowany model doświadczalny uproszczonego układu sterowania umożliwiał kontrolę dwóch napędów - obrotu roboczego głowicy i podawania dodatkowego spoiwa w postaci zimnego drutu oraz ich synchronizację z procesem spawania TIG w formie stałego cyklu roboczego.
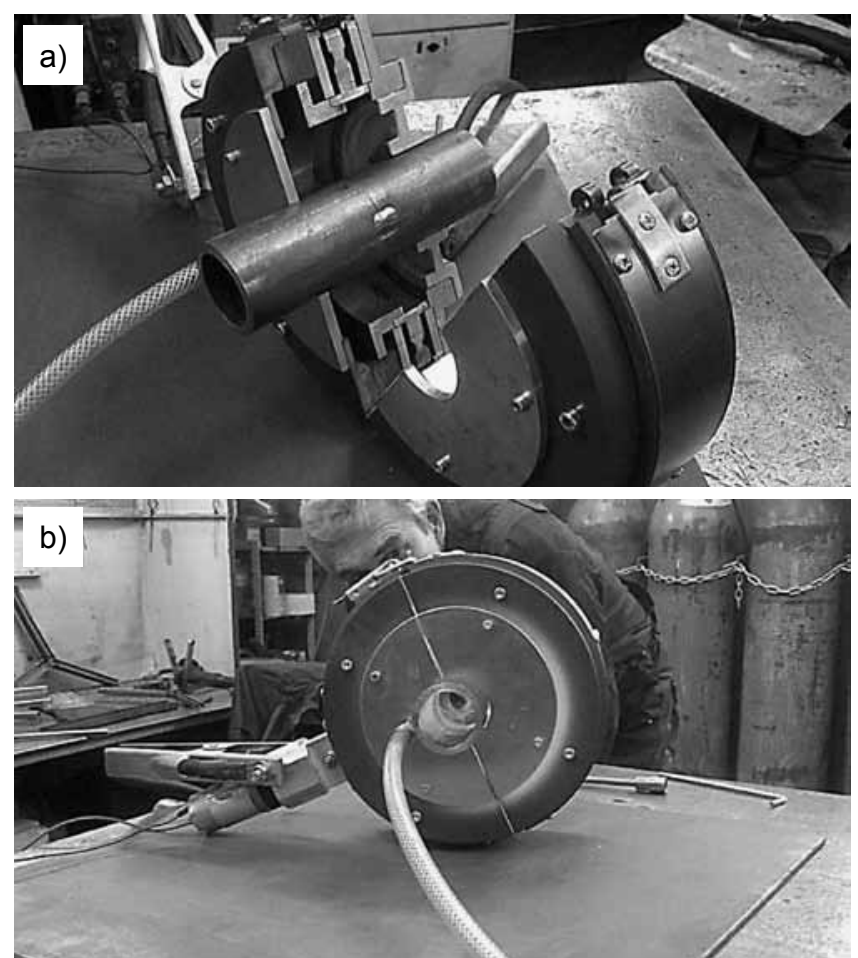

Rys. 7. Model doświadczalny głowicy orbitalnej: a) głowica otwarta po założeniu próbek, b) próby ruchowe podczas spawania

Fig. 7. Experimental model of the orbital welding head: a) opened head with pipe specimen, b) head during test welding

\section{Wdrożenie przemysłowe}

Wytypowane, pozytywnie zweryfikowane rozwiązania i elementy konstrukcyjne modeli zarekomendowano do dalszego wykorzystania w prototypach. Prototypy, o docelowych parametrach projektowanego systemu, były ostatnim stadium badawczym. Dopiero na tej podstawie możliwe było stworzenie projektu optymalnego, zarówno pod względem konstrukcyjnym, jak i użytkowym, a następnie przejście do fazy wdrożenia produkcyjnego.

Ostatecznie system przyjął postać mobilnego stanowiska (rys. 8) o konfiguracji zgodnej ze schematem przedstawionym na rysunku 5.

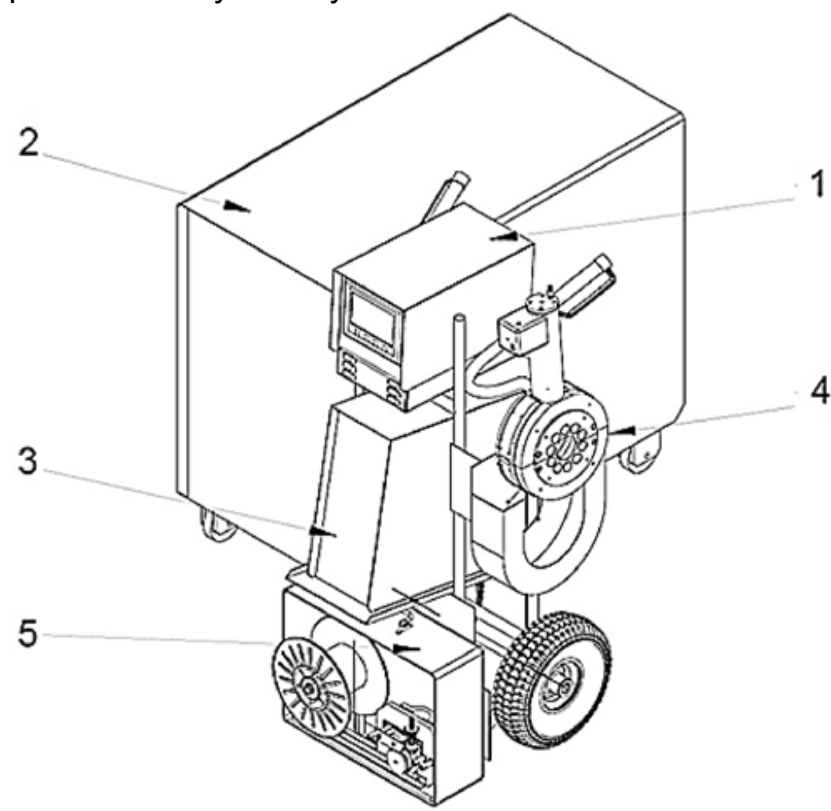

Rys. 8. Wdrożone stanowisko do orbitalnego, doczołowego spawania rur metodą TIG: 1 - nadrzędny układ sterowania, 2 - zasilacz energetyczny z chłodnicą wodną, 3 - regulator źródła zasilającego z jonizatorem, 4 - zamknięta głowica orbitalna, 5 - zespół podawania spoiwa

Fig. 8. The system for orbital butt TIG welding of pipes: 1 - master control device, 2 - water cooled power supplier, 3 - power supplier control system with HF unit, 4 - compact welding head, 5 - filler wire feeder

Wdrożona głowica orbitalna ma postać zamkniętej, uszczelnionej komory gazowej, wewnątrz której porusza się ruchomy pierścień z nietopliwą elektrodą. Obudowa stanowi jednocześnie układ mocująco-centrujący spawanych rur. Montaż głowicy następuje przez zamknięcie jej dwuczęściowego korpusu na spawanych elementach za pośrednictwem wymiennych wkładek dopasowujących. $\mathrm{Na}$ ich powierzchni widać uszczelnione okienka rewizyjne (rys. 9). W wyniku pozytywnej weryfikacji modeli i prototypów zachowano innowacyjny system łożyskowania wewnętrznego pierścienia obrotowego, pełniący jednocześnie rolę układu przekazywania prądu, bez potrzeby stosowania wewnętrznych kabli i złączy (rys. 10).

Konstrukcja spawalniczego źródła energii oparta została na zasilaczu inwertorowym z bezstopniowym zadawaniem parametrów. Wysoka stabilność, powtarzalność parametrów oraz podatność na zdalne sterowanie osiągnięta została dzięki mikroprocesorowemu układowi wewnętrznego sterowania. Osiągnięto zakres regulowanego prądu spawania: $30 \div 200$ A w cyklu P 60\%. Odmiany spawania TIG: AC, DC oraz DC z pulsacją prądu. Napięcie zasilające: 400 V, 3 fazy, $50 / 60 \mathrm{~Hz}$.

Nadrzędny układ sterowania pozwala na kontrolę dwóch napędów - obrotu głowicy i podawania dodatkowego spoiwa w postaci tzw. zimnego drutu. Układ, 


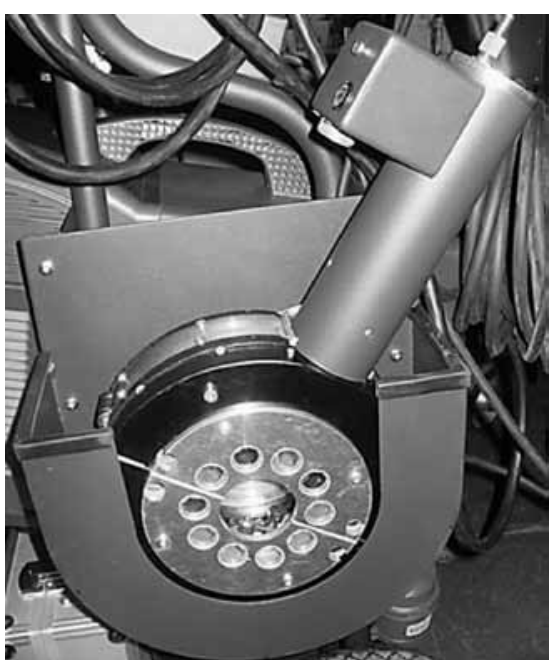

Rys. 9. Wdrożona głowica orbitalna TIG w uchwycie transportowym mobilnego stanowiska

Fig. 9. The commercial version of the compact orbital TIG welding head prepared for delivery

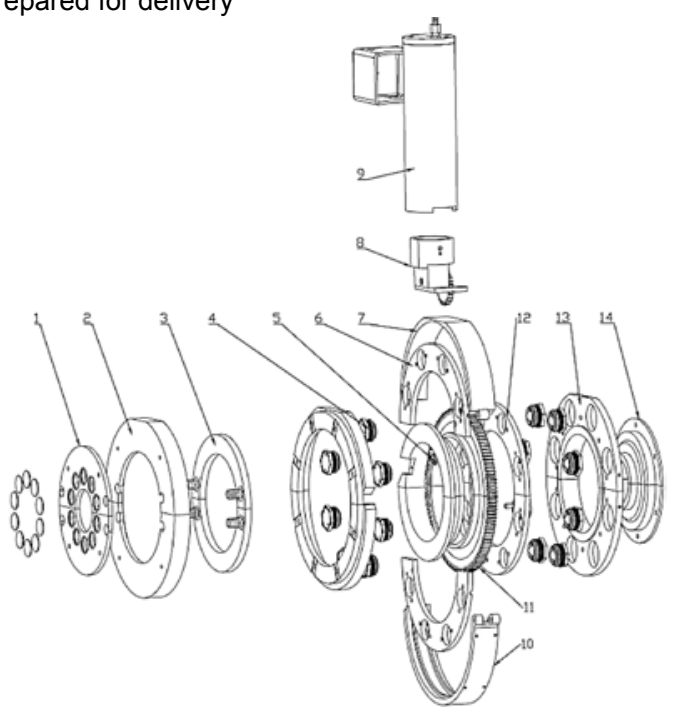

Rys. 10. Schemat wdrożonej zamkniętej głowicy orbitalnej: 1 - wymienne wkładki centrująco-mocujące głowicy, 2 i 13 - osłona boczna, 3 - segmenty układu chłodzenia wodnego, 4 - kulki łożyska i przepustu prądowego, 5 - pierścień mocowania elektrody nietopliwej, 6 i 12 - kosze łożysk, 7 i 10 - obejma głowicy, 8 - przekładnia główna silnika, 9 - osłona silnika napędowego, 11 - wieniec zębaty, 14 - wymienna, rozcięta tulejka centrująco-mocująca głowicy

Fig. 10. Layout of compact TIG welding head: 1 - exchangeable insert of fixing-centering clamp, 2 and 13 - side shields, 3 - elements of water cooling system, 4 - ball-bearing, 5 - ring of non-consumable electrode holder, 6 and 12 - ball bearing baskets, 7 and $10-$ head shields, 8 - main motor gear, 9 - driving motor shield, 11 - gear wheel, 14 - exchangeable fixing-centering sleeve of the head

oparty na sterowniku PLC SIMATIC firmy Siemens, umożliwia precyzyjne zaprogramowanie całego cyklu roboczego, w tym zsynchronizowanie poszczególnych faz ruchu obwodowego elektrody z funkcjami i parametrami procesu - podział obwodu na sektory o zmiennych, programowanych parametrach. Dostępne są następujące funkcje:

- sterowanie automatyczne - programowe,

- start/stop ruchu roboczego i ustawczego z bezstopniową regulacją prędkości w całym zakresie,

- pełna synchronizacja ruchu głowicy, podawania spoiwa i pracy spawalniczego źródła energii,
- zaprogramowany, wcześniejszy nadmuch gazu osłonowego, a następnie jego pozostawienie przez określony czas po zakończeniu spawania,

- synchronizacja zmian przebiegu prądu spawania (także z pulsacją) i podawania dodatkowego spoiwa z fazami ruchu obwodowego elektrody TIG wokół złącza - podział złącza na sektory,

- programowane nałożenie końca spoiny na jej początek (tzw. przekrycie, rys. 11),

- programowe tzw. wypełnienie krateru zsynchronizowane $z$ ruchem elektrody (rys.11),

- możliwość przechowywania programów w pamięci wewnętrznej,

- monitorowanie (pomiar i rejestracja) parametrów spawania,

- obsługa za pośrednictwem pulpitu kontrolno-sterującego z ekranem graficznym, umożliwiającym na wizualizację parametrów spawania.

$Z$ rozeznania realizatorów projektu wynika, że dotychczas nie była produkowana głowica zamknięta z zewnętrznym podawaniem dodatkowego spoiwa w postaci drutu. Istotną trudnością konstrukcyjną głowicy orbitalnej było zapewnienie niezakłóconego podawania spoiwa podczas pełnego obrotu elektrody TIG wokół złącza, przy jednocześnie jak najmniejszych rozmiarach (objętości) samej głowicy, m.in. z uwagi na zapewnienie jak najlepszego dostępu do miejsca spawania oraz zredukowanie ilości gazu osłonowego pompowanego do komory roboczej. Na rysunku 12 pokazano szczegóły mocowania elektrody i wprowadzania spoiwa w obszar łuku (wewnątrz głowicy).

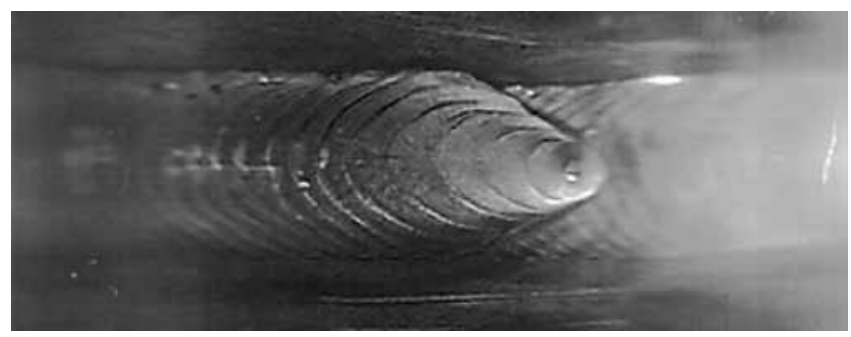

Rys. 11. Przykład działania funkcji przekrycia (nałożenia końca spoiny obwodowej na jej początek) oraz tzw. wypełniania krateru

Fig. 11. An example of orbital weld crater feeling option

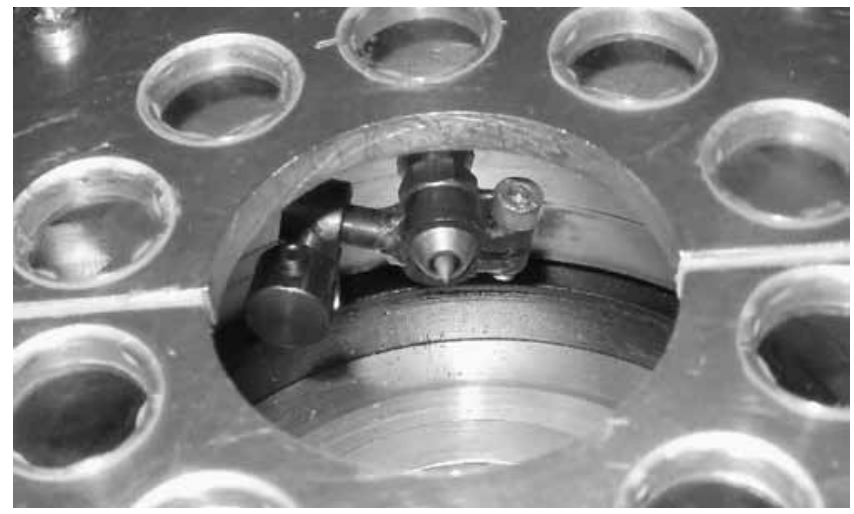

Rys. 12. Mocowanie elektrody i wprowadzanie spoiwa w obszar łuku Fig. 12. A view of the electrode holder and the filler wire feeding nozzle 


\section{Wnioski}

Przedstawione urządzenia powstały na podstawie oryginalnych projektów przy wykorzystaniu nowoczesnych, wspomaganych komputerowo metod projektowania i modelowania oraz najnowszych układów energoelektronicznych, napędowych i sterowania. Uwzględniają potrzeby i możliwości potencjalnych, przede wszystkim krajowych użytkowników, zarówno pod względem ceny, jak i oferowanych możliwości. Stanowią kolejny przykład pomyślnego transferu innowacyjnych projektów i rozwiązań konstrukcyjnych nowych urządzeń technologicznych z jednostek naukowo-badawczych do przemysłu.

$\mathrm{Na}$ szczególną uwagę zasługuje wiele wprowadzonych, innowacyjnych rozwiązań, w tym poszerzony zakres średnic spawanych rur w stosunku do tradycyjnych rozwiązań głowic zamkniętych, niespotykany w tego typu głowicach system podawania dodatkowego spoiwa czy łożyskowania z równoczesnym przekazywaniem prądu spawania.

\section{Literatura}

[1] Cegielski P.: Mechanizacja i automatyzacja procesów spawalniczych. Część 5. W: Kalendarz Spawalniczy. Polska Izba Spawalnicza, Warszawa 2013 (s. 22-46).

[2] Cegielski P.: Robotyzacja. W: Technika spawalnicza w praktyce. Poradnik inżyniera konstruktora i technologa. Red. K. Ferenc. Warszawa, Verlag 2013.
[3] Cegielski P., Kolasa A., Golański D., Sarnowski T., Oneksiak A.: Innowacyjne rozwiązania konstrukcyjne $w$ przemysłowych urządzeniach do automatyzacji procesów spawalniczych. Przeglad Spawalnictwa 1/2013, s. 30-35.

[4] Materiały firmowe ESAB, Fronius, Polysoude, Orbimatic i Magnatech.

[5] Projekt celowy FSNT-NOT Nr ROW-III-204-2011 pn. „Uruchomienie produkcji zautomatyzowanego systemu do orbitalnego doczołowego spawania rur metodą TIG", 2012/2013.

\section{Przegląd Spawalnictwa Welding Technology Review Open Access Library}

Przegląd Spawalnictwa uruchomił możliwość wolnego dostępu do pełnych treści artykułów w ramach Open Access Library. Artykuły w języku angielskim w formacie PDF zamieszczane są na tronie internetowej redakcji: www.pspaw.ps.pl.

Autorów zainteresowanych publikacją w Open Access Library prosimy o przesyłanie artykułów w języku polskim i angielskim. W miesięczniku nastąpi publikacja w języku polskim, a tekst $w$ języku angielskim zostanie zamieszczony na stronie internetowej.

\section{W dniach 6-7 maja 2014 r. odbędzie się V Sympozjum Naukowe \\ Zakładu Inżynierii Spajania Politechniki Warszawskiej współorganizowane przez Studenckie Koło Naukowe „JOINT"}

